\title{
Corrigendum
}

\section{Parkinson's disease: the nutrition perspective - CORRIGENDUM}

\author{
Mícheál Ó Breasail $^{1 *}$, Matthew D. Smith ${ }^{1}$, Emma Tenison ${ }^{1}$, Emily J. Henderson ${ }^{1,2}$ and \\ Fiona E. Lithander ${ }^{1}$ \\ ${ }^{1}$ Population Health Sciences, Bristol Medical School, University of Bristol, 1-5 Whiteladies Road, \\ Bristol BS8 1NU, UK \\ ${ }^{2}$ Royal United Hospital Bath NHS Foundation Trust, Combe Park, Bath BAI 3NG, UK
}

The original version of this article was published with incorrect formatting of an author's name. The first author is Mícheál Ó Breasail and the correct and full last name is Ó Breasail. The original version has now been updated to reflect this.

\section{Reference}

Ó Breasail, M., Smith, M., Tenison, E., Henderson, E., \& Lithander, F. (2021). Parkinson's disease: The nutrition perspective. Proceedings of the Nutrition Society, 1-15. doi:10.1017/S0029665121003645 